УДК 537.8

\title{
РАССЕЯНИЕ СВЕТОВЫХ ВОЛН НА КОНЕЧНЫХ РЕШЕТКАХ ИЗ МЕТАЛЛИЧЕСКИХ НАНОЛЕНТ: МЕТОД НАЙСТРЕМА И РЕЗОНАНСНЫЕ ЭФФЕКТЫ
}

\author{
ШАПОВАЛ О. В. \\ Институт радиофизики и электроники Национальной Академии наук Украины, \\ Украина, Харьков, 61085, ул. Проскуры 12
}

\begin{abstract}
Аннотация. Предложен эффективный и быстро сходящийся численный алгоритм для моделирования задач рассеяния световых волн на конечных решетках, состоящих из тонких (тоньше, чем длина волны в свободном пространстве) металлических нанолент. Модель основана на использовании обобщенных граничных условий (ОГУ), которые позволяют исключить из рассмотрения поле внутри каждой из лент и свести двумерную краевую задачу к одномерным системам сингулярных/гиперсингулярных интегральных уравнений (ИУ). Полученные ИУ решаются численно с помощью метода Найстрема и квадратурных формул интерполяционного типа обеспечивая гарантированную сходимость и контролируемую точность. Приведены результаты расчетов характеристик рассеяния и поглощения света на решетках, состоящих из серебряных нанолент, в зависимости от ширины и толщины лент, периода решетки. Изучена природа резонансных явлений - интенсивное рассеяние и поглощение света при возбуждении плазмонных мод (плазмонов) и решеточных мод, порожденных периодичностью
\end{abstract}

Ключевые слова: тонкая нанолента; обобщенные граничные условия; сингулярные интегральные уравнения; гиперсингулярные интегральные уравнения; метод Найстрема; рассеяние и поглощение волн; плазмон; решеточный резонанс

\section{1. ВВЕДЕНИЕ}

Наноразмерные материалы, устройства и технологии - постоянно развивающаяся и расширяющаяся область науки и производства, стремительно порождающая новые направления, такие как нанофотоника и нанооптика. Резонансные эффекты при рассеянии и поглощении световых волн металлическими нанообъектами связаны главным образом с поверхностными плазмонными резонансами и имеют широкий спектр практических применений. Так при создании биосенсоров плазмонные эффекты позволяют существенным образом улучшить возможности обнаружения, идентификации и диагностики биологических объек- тов за счет усиления интенсивности флуоресценции.

Благодаря современным технологиям напыления, осаждения и вытравливания, нанонити и тонкие наноленты из благородных металлов (серебро, золото) прочно вошли в состав многих устройств терагерцевого и светового диапазонов волн (например, наноантенны и биосенсоры) [1-5]. Периодические решетки из нанонитей и нанолент привлекают особое внимание. Это связано с недавно обнаруженными эффектами аномального отражения, прохождения и излучения, а также усиления ближнего поля [3-6]. Такие явления наблюдаются вблизи так называемых аномалий Рэлея соответствующих бесконечных решеток [6] и, в самом 